\title{
The Issue of Register-Style in Language Teaching: Analyzing Register-Style Errors of Learners of Cantonese as a Second Language
}

\author{
Siu-lun Lee, Kin Wing Kevin Chan \\ The Chinese University of Hong Kong, Hong Kong, China \\ Email: slee@cuhk.edu.hk
}

Received 15 July 2015; accepted 9 August 2015; published 12 August 2015

Copyright (C) 2015 by authors and Scientific Research Publishing Inc.

This work is licensed under the Creative Commons Attribution-NonCommercial International License (CC BY-NC).

http://creativecommons.org/licenses/by-nc/4.0/

(c) () \& 8 pen Access

\begin{abstract}
This paper analyzes the register-style errors of learners of Cantonese as a second language. It is a pilot study of building up learners' corpus containing learners' speeches and storytelling samples of about 5000 minutes. All data are collected from spontaneous speeches delivered and storytelling by 44 Cantonese $\mathrm{L} 2$ learners during different learning stages. The data shows examples containing utterances and samples with register-style errors produced by Cantonese L2 learners. Examples show violation of rules in register-style grammar by using inappropriate register-style or mingling different levels of formality in particular language context. The research is a preliminary analysis of register-style grammar in Cantonese and discusses some implications and suggestions for teaching Cantonese as a Second Language as well as in teaching Chinese as a Second Language.
\end{abstract}

\section{Keywords}

Pragmatics, Register, Style, Error Analysis, Teaching Cantonese as a Second Language, Teaching Chinese as a Second Language

\section{Introduction and Background of the Study}

After years of development, linguistics have been developed into various sub-fields, to name a few, there are structural linguistics, sociolinguistics, anthrolopolical linguistics, cognitive linguistics, psycholinguistics etc. Each sub-field has their own assumptions and focuses of study. When we look at language teaching, no matter second language teaching or foreign language teaching are concerned, the various sub-fields of lingusitics have 
different pedagogical implications which affect curriculum design, textbook preparation, teaching methodology as well as the development of educational technologies nowadays. Language teaching employing structural linguists' views focuses on the phonetics, morphophonological and syntactic rules of the target language. Language teaching adopting psycholinguistic models pays their attention to aspects related to biological aspect of language acquisition, neuroscience, cognitive science. Language teaching using sociolinguistic frameworks put the efforts in language as a tool to communicate with other interlocutors and to establish or maintain social relationships with other target language users.

If we look at teaching Chinese as a second language (CSL), a blooming industry/field in recent years, early pedagogical concerns in CSL tends to follow structural linguistic theories (Chao, 1968; DeFrancis, 1963, 1964, 1966) but currently there is a tendency to switch to the social and practical functions of the Chinese language and its varieties. Putonghua (Mandarin Chinese) acts as a language for business (Zhang, 2010), language for study and a language for wider communication (Li, 2007) in the Chinese speaking world. Other Chinese varieties, such as Cantonese, Shanghainess etc. act as languages used for daily communication in particular regions. Scholars adopting sociolinguistic views in CSL (Tao, 1996; Feng, 2006, 2010, 2011; Su \& Tao, 2014) started to research on the pragmatic aspects and social functions of Putonghua (Li, 2006; Li, 2006; Zhao, 2008) and standard written Chinese (Feng, 2006; Feng, Wang, \& Huang, 2008). Su \& Tao (2014) pointed out that the context of communication should be put in CSL curriculum and teaching materials. Feng $(2010,2011)$ noticed that Chinese has various forms of yuti (register-style), which is highly related to the situational contexts, such as status of addressers \& addressees, settings where the conversations is taking place. He further suggested that yuti has its social functions and should be analyzed as part of the Chinese grammar. Employing incorrect yuti in inappropriate settings or to inappropriate addressees, is not just an issue of embarrassment or inappropriateness, but relates to grammaticality issues (Feng, 2010).

This paper follows the sociolinguistic views in CSL to research on the issue of register-style in teaching and learning Cantonese as a second language. Cantonese is a language variety widely used in Hong Kong, Macau, Southern part of China, and with some overseas Chinese (Matthews \& Yip, 1994). It has been a number of learners from different parts of the world learning Cantonese as a second language in Hong Kong (Lee, 2005). A learners' corpus had been built to collect features of learners of Cantonese as a second language. This paper focuses particularly on the features or errors when register-style rules are ignored.

\section{Language in Communication}

Firth (1957) argued that, in order to convey meaning with a language, there are several major components namely, the phonetic function, the lexical \& morphological system, the syntactic structure and the awareness of the "context of situation". Apart from phonological, morphological and syntactic rules, Firth (1957) identified that "the function of a complete locution in the (typical) context of situation" is another important element for a language to convey meaning. Many lingusits (Firth, 1957; Hymes, 1972; Thomas, 1995) regarded "context" as an important aspect of language. Similarly, Hymes (1972) argued that the "rule of speaking" should be associating "particular modes of speaking" with "particular setting and activities". Thomas (1995) had proposed that "context" can be classified into three types: 1) physical context (date, time, location, theme, etc of the conversation); 2) social context (the social status of the speaker and the addressee, etc.); and 3) linguistic context (what language is being used and why).

This paper focuses on the relationship among language use, physical contexts and social contexts as described by Thomas (1995). In CSL research, teachers tend to spend a lot of class time in training students with linguistic knowledge, but paying relatively little attention on language use. Jiang (2013) analyzed the phonetic and phonological errors of L2 Chinese learners. Du (2006), Xu (2010) and Wang (2011) studied the lexical errors of CSL learners. Lai (2006) studied the misuse of modal auxiliaries when L2 Chinese learners were learning the language. There were very little research on the errors occurred when CSL learners neglected to associate "particular modes of speaking” with "particular setting and activities" as discussed in Hymes' (1972) work. One can argue that Chinese, unlike many European languages and some Asian languages, does not employ a politeness stragegy on lexical and syntactic level. For examples, "vous" (polite form of the pronoun "you") \& "tu" (casual form of "you") in French are associated with conjugation in verbs and related forms on syntactic level; and the well-structured honorific systems in Japanese (Ide, 1982; Okamoto, 1999; Lauwereyns, 2002; Tanaka, 2010) and Korean (McBrian, 1978; Winter \& Grawunder, 2012), in which associated with morphological markers and 
verb conjugation in different conversational settings. According to Siewierska (2013) and Helmbrecht (2013) who worked in the project "The World Atlas of Language Structure Online (WALS)", Chinese does not explicit a sophisticated honorific system as compared to Korean and Japanese. However, does it mean that the physical contexts and social contexts are not important in Chinese?

The answer is "no", some scholars (Tao, 1996; Feng, 2010, 2011) argued that different linguistic forms are adopted when Chinese is used in different social settings and activities. Feng $(2010,2011)$ discussed what he called 語體 yuti in Chinese. He cleared the illusion that laments always regard written Chinese as formal and sopken Chinese as informal. He suggested the diachotomy of "formal verses informal" appears in written Chinese as well as in spoken Chinese. He proposed to use "level of formality (正式度 zhengshidu)" to analyze Chinese when it is used in different settings and activities. For examples, chatting among family members could be regarded as a situation with lower level of formality while speaking in a meeting with government officials concerning certain government policies is a situation with higher level of formality. The choice of words or expressions need to change according to the level of formality. There are many expressions to convey "to compose/revise teaching materials” in Putonghua (Feng, 2010: 404-405) as shown below.

Level 0 formality 編教材

Level 1 formality 編寫教材

Level 2 formality 教材編寫、教材的編寫

Level 3 formality 對教材進行編寫/改編

From Feng's (2010) examples above, there are several linguistic aspects that affects the representation of formality in the expressions since each example differ from one another in terms of prosodic features, word order and syntactic structures. The choice of words with different "level of formality" suggested by Feng (2010) depends on the physical contexts (time, venue, etc.) and social contexts (social status of the addressers and the addressees) as discussed by Thomas (1995).

Chan \& Lee (2014) conducted a pilot study by collecting in-class sponteanous speeches of L2 Cantonese learners with formal, semi-formal and informal situational settings. They reported that L2 Cantonese learners sometimes produced "grammatical but unacceptable/inappropriate" utterance while learning Cantonese, the target language. By Chan \& Lee (2014), “unacceptable” meant the utterances were not deemed acceptable by native speakers in two ways, the first type is that the L2 Cantonese learners mismatched the language use with the physical \& social contexts in terms of formality and the second type of unacceptable utterances is that the L2 Cantonese learners were "mingling" linguistic forms or elements with different level of formalities on sentence level. Chan \& Lee (2014) was a preliminary pilot study but pointed out that register-style, physical contexts and social contexts are important aspects towards effective teaching and learning of Cantonese as a second language.

\section{Register-Style in Sociolinguistics}

Register and style are not new topics in linguistic studies. Halliday \& Hasan (1976) pointed out that registers are "linguistic features which are typically associated with a configuration of situational features - with particular values of the field, mode and tenor..." (p. 22). According to Halliday \& Hasan (1976), "field" is "the total event, in which the text is functioning, together with the purposive activity of the speaker or writer" (p. 22). "Mode" is "the function of the text in the event, including both the channel taken by language-spoken or written, extempore or prepared" (p. 22). "Tenor" is "the type of role interaction, the set of relevant social relations, permanent and temporary, among the participants involved" (p. 22). These three values—field, mode and tenor-are the determining factors for the linguistic features of the text. Crystal (1985) points out that Halliday \& Hasan's "tenor" is a roughly equivalent term for "style", which is a more specific alternative used by linguists to avoid ambiguity (p. 292).

Although the use of the term "registers", "styles" and "genre" vary from scholars to scholars, some previous studies showed that the issue of "register-style" exists in Chinese (Pan, 1986; Yu, 2003; Liu, 2004). Pan (1986) and Yu (2003) analyzed several styles of Chinese adopted by news reporters, law-practitioners, advertisers, government officials, academics and artists, etc. Liu (2004) noticed scholars in Chinese linguistics tend to use different styles (風格 fenge in her words) of Chinese in different physical and social contexts. Feng (2010, 2011) explicitly stated that yuti (register-style) plays a role in CSL pedagogical grammar. Previous research indicated that the issue of "register-style" is cruical in analyzing the linguistic structure of Chinese as well as in teaching and learning of Chinese as a second language. This paper studies the issues of "register-style" in Cantonese and 
teaching Cantonese as a second language.

\section{The Research}

Two research questions were set out for this research and a corpus of L2 Cantonese learners were built. The corpus was analyzed in terms of errors in "register-style" and "acceptability". The two research questions are:

1) What are the factors that affect "acceptablity"?

2) What are the possible markers of formality in Cantonese? Prosody? Lexicon? Or Syntactic structures?

The L2 Cantonese learners' corpus consisted of 5000 minutes of utterances samples from 44 Cantonese L2 learners (who had experienced 195 - 780 hours of formal class time). Table 1 shows the biographical data of the learners.

All the subjects were invited to denote a conversational play or an oral presentation every week or every 2 weeks. Topics and settings of the conversational plays or presentations are shown in Table 2 below. All the plays and presentations were recorded and transcribed. The main reason for analyzing the conversational plays or oral presentation was that Cantonese is a spoken language and analyzing recorded oral materials was more appropriate for the research purpose. The topics and social settings of the plays and presentations were set according to different physical and social contexts. All the subjects were given 1 week to prepare the plays or presentations so that the features or errors were not ad hoc mistakes or slip of the tongue, but are systematic features recorded while they were learning the target language.

The transcribed data were put into the corpus. 20 native speakers were invited to act as raters to evaluate the plays or presentation in terms of acceptability. The 20 native speakers were asked to rate the utterances in a 5-point Likert scale by judging whether the utterances were "grammatical", "acceptable" and "appropriate". Interviews were conducted with the native speaker raters to elicit a detailed account concerning their rating and perceptions towards the utterances. Similar research methodology was adopted by Corder (1967) to study language acquisition of L2 learners. The 20 native speakers raters were educated adults who were university students and were randomly selected from the university population in Hong Kong.

Table 1. Biographical data of the subjects.

\begin{tabular}{ccc}
\hline Number of subjects & Exposure to Cantonese & Nationality \\
\hline 6 & 195 hours of class time & Mexico, Taiwan (China), Philippine, Japan, Spain \\
10 & 390 hours of class time & Panama, Japan, USA, UK, Philippine, Germany, Norway \\
18 & 585 hours of class time & Japan, Korea, UK, USA, Australia, Italy, India \\
Total $=44$ & 780 hours of class time or above & Australia, Japan, USA, Canada, UK, Korea, Philippine, Russia \\
\hline
\end{tabular}

Table 2. Topics and settings of the conversational plays or oral presentations.

\begin{tabular}{|c|c|c|}
\hline Presentation types & Social contexts & Sample topics \\
\hline Introduction & Talking to friends (informal) & $\begin{array}{l}\text { Say something about your family. } \\
\text { Say something about your country. }\end{array}$ \\
\hline Description & Talking to friends (informal) & $\begin{array}{l}\text { The happiest birthday party ever. } \\
\text { What did you do during the holidays? }\end{array}$ \\
\hline Discussion on societal issues & In work place (semi-formal) & $\begin{array}{l}\text { Should citizen express their views towards the government } \\
\text { through protesting? } \\
\text { How to solve the pollution problem in Hong Kong? }\end{array}$ \\
\hline Expression of personal opinion & In work place (semi-formal) & $\begin{array}{l}\text { Do you agree that studying in universities can secure a } \\
\text { promising future? } \\
\text { Is it a problem to change your job frequently? }\end{array}$ \\
\hline Report & In a workshop (semi-formal) & Summary of a field trip \\
\hline Request & $\begin{array}{l}\text { In work place with government } \\
\text { officials (formal) }\end{array}$ & $\begin{array}{l}\text { Make a call to a government office to request for some } \\
\text { information on behalf of your company }\end{array}$ \\
\hline
\end{tabular}




\section{Data Analysis and Discussion}

In the learners' corpus, two types of errors had been identified. The first type of errors was "discourse-context mismatch". Context here meant the physical and social contexts (Thomas, 1995). In our data, it is discovered that learners sometimes cannot use their language or do not have the awareness to the pragmatic use of the target language according to the formality of the physical and social contexts. Examples of using consistently informal or causal expressions in formal settings or using overly formal expressions in casual settings are regarded as odd and inappropriate by native speakers. This kind of errors exist because of the lack of ability or awareness to use the target language appropriately according to different physical and social contexts.

For the second type of errors, we would call it "mingling". This type of error occurred when a learner employed both formal and informal expressions within the same sentence, in the same utterance or in the same connected discourse. Native speakers regarded this type of errors unacceptable, no matter it appeared understand whatever physical and social contexts. The second type of errors has some theoretical implications.

In example (1) below, the conversation setting was "talking to your friends in a casual dinner. The learner used informal elements like 你哋都識架 “you all know (him)”, 佢係邊個 “who he is”, 師奶 “housewife (casual)" etc. together with a formal lexicon 猜測 “to speculate” instead of informal synonyms like 估. Native speaker raters commented that the utterance was inappropriate and unacceptable and they pointed out that. 猜測 "to speculate" did not match with other components within the same sentence.

1) “唔使講咁多, 我講嘅呢個年青人, 你吔都識架! 中環 OL 同街市師奶都識佢! 請你吔猜測吓佢係邊 個?” (Student LSM: 15JUL2014, Topic: A story of a young man)

This kind of errors are always analyzed as "incorrect choice" of words and expressions. However, if we further analyze such errors, the "incorrectness" actually are violating certain "rules". Such examples show that production of sentences and discourses are bounded by the formality level of physical and social contexts. "Mingling" of formal and informal expressions within a sentence or discourse in a given context was not acceptable by native speakers. Once the formality level of the sentences or discourses were determined, components should abide to certain rules according to formality level and such "rules" should be similar to the sentence agreement rules as in traditional syntactic analysis.

Example (2) below shows a post-trip report presented in a formal setting. The utterances were rated by native speakers as acceptable and appropriate. The learner had manipulated a number of formal expressions like 服務 態度 “service attitude”, 採用 “to use”, 對待 “to treat”, 提供 “to provide” etc. when producting the utterances in a formal setting.

2) “XX 航空公司, 時常注重服務態度, 為咗每位乘客嘅旅途愉快, 艙務員要接受訓練學會點樣對待乘 客, 佢吔仲會採用良好嘅服務態度對待乘客. 每日為機上乘客提供一碗面, 同埋提供啤牌, 可以令到乘客 鬆弛神經，消愁解悶.” (Student FJSJ, 1DEC2013. Topic: Formal post-trip report)

In Example (2), we think that formality level of Cantonese can be expressed by prosody. For instance, the meaning “to write” can be denoted by 寫 or 編寫, while the meaning “book” can be denoted by 書 or 書籍. The degrees of formality of those expressions with one syllable $[\sigma]$ are different from the degrees of formality of those with two syllables $[\sigma \sigma]$. Under this premise, mingling words with one syllable with words with two syllables (e.g.: 編寫+書 or 寫+書籍) could be regarded as ungrammatical/unacceptable. Such phenomenon can also be found in our Cantonese learner corpus as well. Some examples are listed in Table 3.

In Table 3, combinations $*[\sigma]+[\sigma \sigma]$ and $*[\sigma \sigma]+[\sigma]$ are unacceptable in Cantonese, similar to the observation made by Feng (2010) in his research on Chinese. The examples shown in Table 3 indicate that prosodic features of phrases or expressions are related to the expression of formality level and "mingling" of phrases or expressions with prosodic features expressing different level of formality is not acceptable or deems to be inappropriate to native speakers.

"Mingling" not only happened on lexical level, but also appeared when the learners were adopting a syntactic structure with higher level of formality and mix with phrases and expressions with lower level of formality. Example (3) below shows a learner tried to introduce the advantages of liberal studies to the students in Hong Kong in a semi-formal seminar. The informal lexicon 超級好 “very good (super good)" and the formal element 有益於 "to benefit" mingled in the same discourse. Similar to Example (1), Example (3) below was also classified as inappropriate and unacceptable by native speakers. 
Table 3. Formality and prosody in Cantonese.

\begin{tabular}{|c|c|c|c|}
\hline Meaning & {$[\sigma \sigma]+[\sigma \sigma]$} & {$[\sigma]+[\sigma]$} & $*[\sigma]+[\sigma \sigma] / *[\sigma \sigma]+[\sigma]$ \\
\hline The poor (people) & 貧窮人士 & 窮人 & *窮人士 $/$ *貧窮人 \\
\hline The worker / staff & 工作人員 & 工人/職員 & *工人員/*工作員 \\
\hline To payback the debt & 償還債務 & 還債 & *還債務/*償還債 \\
\hline To be interviewed & 接受訪問 & 受訪 & *受訪問/*接受訪 \\
\hline
\end{tabular}

3) “...我覺得呢啲通識教育真係對學生超級好, 通識教育真係有益於學生明白社會國家，世界嘅問題...” (Student GYJS: 27SEP2013, Topic: My view on the liberal studies subject in Hong Kong)

There were more examples showing this kind of “mingling”. We can look at Examples (4) and (5) below.

4) “雖然住係老人院悶到嘔, 但係如果佢地嘅仔女探佢地嘅話, 非開心到飛起不可嘅喇” (Student SCYJ: 150CT2010; Topic: Should we send our parents to the homes for elderly?)

5) “平時我地諗讀書多啲, 搵兩餐容易啲, 人工會高啲. 因為咁, 大部分爹地媽咪同老師都會以入大學 讀書為重要架喇” (Student MDY: 09NOV2011; Topic: Do you agree that studying in universities can secure a promising future?)

In Example (4), the learner mingled informal elements like 開心到飛起 “very happy (so that one can fly)” with a formal syntax structure 非 ...不可“definitely be”. In Example (5), the learner employed informal coordinating clause ...啲 ...啲 "the more..., the more..." to illustrate the relationship between education background and job opportunity and in the same discourse, another formal syntax structure 以... 為...“保 regard... as...” was also used (以入大學讀書為重要 which means “regarded studying in an university as an important thing”).

Previous scholars focused on prosody and lexicons as markers of formality (Feng, 2010, 2011) throw some lights on our analysis. In our study on the Cantonese learners' corpus, it is discovered that prosody, lexicon, as well as syntactic structures can affect the level of formality of utterances in Cantonese.

\section{Conclusions}

Foreign language teaching is not satisfied merely in grammatical competence, but put a lot of emphasis on the pragmatic use of the target language. The research data in our study indicates that learners lack the ability or the awareness of appropriateness and language use in different physical and social contexts. The lacking of such awareness may result in difficulties for learners to use the language effectively in real world situations. In order to train learners with such ability or awareness, suitable teaching methodology, curriuclum design and teaching materials should be developed. In the field of teaching Cantonse as a second language, traditional teaching materials are based on developing grammatical competence (Chao, 1968; Huang \& Kok, 1973; Lau, 1975). There are still room for further research on teaching materials, teaching methodology and curriculum design in the field.

There is also a lack of theoretical framework concerning register-style grammar in Cantonese. Although the issue of formality in Cantonese has been addressed in some previous studies on Cantonese grammar (Matthews \& Yip, 1994), detailed theoretical analysis on the issue of register-style issue is lacking. One important aims of our attempts to analyze the register-style errors appeared in L2 Cantonese learners' utterances is to draw the attention of scholars that register-style is important not only in the teaching of Cantonese as a second language, but also worth to study from a theoretical perspective. Our study ponits out that there are relationship between prosodic features and level of formality in Cantonese. The choice of lexical items is another factor that affects the level of formality of utterances in Cantonese. There may be other linguistic factors, such as word order, etc that could affect level of formality. We would like to do follow-up research to explore the issue further in the near future.

\section{References}

Chao, Y. R. (1968). A Grammar of Spoken Chinese. Berkeley: University of California Press. 
Corder, S. P. (1967). The Significance of Learners' Errors. International Review of Applied Linguistics in Language Teaching, 5, 161-170. http://dx.doi.org/10.1515/iral.1967.5.1-4.161

Crystal, D. (1985). A Dictionary of Linguistics and Phonetics. Oxford: Basil Blackwell.

DeFrancis, J. (1963). Beginning Chinese. Yale: Yale University Press.

DeFrancis, J. (1964). Intermediate Chinese. Yale: Yale University Press.

DeFrancis, J. (1966). Advanced Chinese. Yale: Yale University Press.

Firth, J. R. (1957). Papers in Linguistics 1934-1951. London: Oxford.

Halliday, M. A. K., \& Hasan, R. (1976). Cohesion in English. London: Longman.

Helmbrecht, J. (2013). Politeness Distinctions in Pronouns. The World Atlas of Language Structures Online. http://wals.info/chapter/45

Huang, P. P.-F., \& Gerald, P. K. (1973). Speak Cantonese: Book 1. New Haven: Far Eastern Publications.

Hymes, D. H. (1972). On Communicative Competence. In J. B. Pride, \& J. Holmes (Eds.), Sociolinguistics: Selected Readings (pp. 269-293). Harmondsworth: Penguin.

Ide, S. (1982). Japanese Sociolinguistics Politeness and Women’s Language. Lingua, 57, 357-385. http://dx.doi.org/10.1016/0024-3841(82)90009-2

Lau, S. (1975). Advanced Cantonese. Hong Kong: The Government Printer.

Lauwereyns, S. (2002). Hedges in Japanese Conversation: The Influence of Age, Sex, and Formality. Language Variation and Change, 14, 239-259. http://dx.doi.org/10.1017/s0954394502142049

Lee, S.-L. (2005). History and Current Trends of Teaching Cantonese as a Foreign Language: Investigating Teaching Approaches. EdD Dissertation, Leicester: University of Leicester.

Matthews, S., \& Yip, V. (1994). Cantonese: A Comprehensive Grammar. London: Routledge.

McBrian, C. D. (1978). Language and Social Stratification: The Case of a Confucian Society. Anthropological Linguistics, 20, 320-326.

Okamoto, S. (1999). Situated Politeness: Manipulating Honrific and Non-Honorific Expressions in Japanese Conversation. Pragmatics, 9, 51-74. http://dx.doi.org/10.1075/prag.9.1.05oka

Siewierska, A. (2013). Gender Distinctions in Independent Personal Pronouns. The World Atlas of Language Structures Online. http://wals.info/chapter/44

Tanaka, L. (2010). Is Formality Relevant? Japanese Tokens Hai, ee and un. Pragmatics, 20, 191-211. http://dx.doi.org/10.1075/prag.20.2.04tan

Tao, H.-Y. (1996). Units in Mandarin Conversation: Prosody, Discourse, and Grammar. Amsterdam/Philadelphia: John Benjamins. http://dx.doi.org/10.1075/sidag.5

Thomas, J. (1995). Meaning in Interaction: An Introduction to Pragmatics (Learning about Language). London and New York: Longman.

Winter, B., \& Grawunder, S. (2012). The Phonetic Profile of Korean Formal and Informal Speech Registers. Journal of Phonetics, 40, 808-815. http://dx.doi.org/10.1016/j.wocn.2012.08.006

陳健榮, 李兆麟(2014). 粵語二語學習者的語體偏誤分析. In 李兆麟, 謝春玲, 吳偉平(編), 語言學與華語二語教學: 語用能力培飬的理論與實踐(頁碼: 225-236). 香港: 商務印書館. [Chan, K. W., \& Lee, S. (2014). Analyzing Yuti Errors of Learners of Cantonese as a Second Language. In S.-L. Lee, C.-L. Xie, \& W.-P. Wu (Eds.), Linguistics and CSL Teaching and Learning: Theories and Practices in the Training of Pragmatic Abilities (pp. 225-236). Hong Kong: The Commercial Press.]

杜豐青(2006). 韓國學生漢語詞語偏誤分析. 安陽師範學院學報, 1 期, 102-104. [Du, Y. (2006). Analysis of the Mistakes Made by the Korean Students in the Usage of Chinese Vocabulary. Journal of Anyang Teachers College, No. 1, 102-104.]

馮勝利(2006). 漢語書面用語初編. 北京: 北京語言大學出版社. [Feng, S. (2006). Expressions of Written Chinese. Beijing: Beijing Language and Culture University Press.]

馮勝利(2010). 論語體的機制及其語法屬性. 中國語文, 5 期, 400-412. [Feng, S. (2010). On Mechanisms of Register System and Its Grammatical Property. Studies of the Chinese Language, No. 5, 400-412.]

馮勝利(2011). 語體語法及其文學功能. 當代修辭學, 4 期, 1-13. [Feng, S. (2011). Thegrammar of yuti and Its Function in Literature. Contemporary Rhetoric, No. 4, 1-13.]

馮勝利, 王潔，黃梅(2008). 漢語書面語體莊雅度的自動測量. 語言科學, 2 期, 113-126. [Feng, S., Wang, J., \& Huang, M. (2008). An Automatic Feature Checking Algorithm for Degree of Formalities in Written Chinese. Linguistic Science, No. 2, 113-126.] 
姜永超(2013). 外國留學生漢語語音意識偏誤及反思. 華章, 13 期, 184. [Jiang, Y. (2013). The Errors and the Introspection on the Consciousness of the Chinese Phonetics of Foreign Students. Magnificent Writing, No. 13, 184.]

賴鵬(2006). 漢語能願動詞語際遷移偏誤生成原因初探. 語言教學與研究, 5 期, 67-74. [Lai, P. (2006). A Study on the Causes of Interlingual Transfer Errors in the Acquisition of Chinese Modal Auxiliaries. Language Teaching and Linguistic Studies, No. 5, 67-74.]

李泉(2006). 對外漢語課程、大綱與教學模式研究. 北京: 商務印書館. [Li, Q. (2006). Duiwai Hanyu Kecheng Dagang yu Jiaoxue Moshi Yanjiu. Beijing: The Commercial Press.]

李曉琪(2006). 對外漢語文化教學研究. 北京: 商務印書館. [Li, X.-Q. (2006). Duiwai Hanyu Wenhua Jiaoxue Yanjiu. Beijing: The Commercial Press.]

李宇明(2007). 關于《中國語言生活綠皮書》. 語言文字應用, 1 期, 12-19. [Li, Y. (2007). On Green Paper on Language Situation in China. Applied Linguistics, No. 1, 12-19.]

劉叔新(2004). 語言學與文學的牽手: 劉叔新自選集. 天津: 南開大學出版社. [Liu, S. (2004). The Association between Linguistics and Literature: A Personal Anthology of Liu Shuxin. Tianjin: Nankai University Press.]

潘慶雲(1986). “漢語語體學”應成為一門獨立的科學. 浙江師範大學學報(社會科學版), 1 期, 93-97. [Pan, Q. (1986). "The Study of Register in Chinese" Should Become an Independent Science Subject. Journal of Zhejiang Normal University (Social Science), No. 1, 93-97.]

蘇丹潔, 陶紅印(2014). 話語語用學與口語教材的編寫和教學: 以 Working With Spoken Chinese 為例. In 李兆麟, 謝 春玲, 吳偉平(編), 語言學與華語二語教學: 語用能力培飬的理論與實践(頁碼: 144-162). 香港: 商務印書局. [Su, D., \& Tao, H.-Y. (2014). Teaching Discourse Pragmatics in the Spoken Mode: The Case of Working with Spoken Chinese. In S.-L. Lee, C.-L. Xie, \& W.-P. Wu (Eds.), Linguistics and CSL Teaching and Learning: Theories and Practices in the Training of Pragmatic Abilities (pp. 144-162). Hong Kong: The Commercial Press.]

王新青(2011). 民族學生漢語詞語的偏誤分析. 長春教育學院學報, 5 期, 80-81. [Wang, X. (2011). An Error Analysis of the Chinese Vocabularies of Ethnic Students. Journal of Changchun Education Institute, No. 5, 80-81.]

徐威(2010).韓國留學生使用連詞“還有”的偏誤分析及教學策略. 北京大學研究生學志, 3 期, 59-70. [Xu, W. (2010). A Study on Korean Learners' Biased Errors and Teaching Strategies of the Conjunction “haiyou”. Graduate Students' Journal of Peking University, No. 3, 59-70.]

于根元(2003). 應用語言學概論. 北京: 商務印書館. [Yu, G. (2003). An Outline of Applied Linguistics. Beijing: Commercial Press.]

張黎(2010). 商務漢語口語的話語特征. 漢語學習, 3 期, 90-94. [Zhang, L. (2010). The Discourse Features of Oral Business Chinese. Chinese Language Learninging, No. 3, 90-94.]

趙金銘(2008). 漢語作為第二語言教學：理念與模式. 世界漢語教學, 1 期, 93-107. [Zhao, J.-M. (2008). Concept and Mode of Teaching Chinese as a Second Language. Chinese Teaching in the World, No. 1, 93-107.] 